\title{
Correction to: What do students believe about effective classroom management? A mixed-methods investigation in Western Australian high schools
}

\author{
Helen Egeberg ${ }^{1}$ (D) . Andrew McConney ${ }^{2}$
}

Published online: 9 January 2019

(c) The Author(s) 2019

\section{Correction to: Aust. Educ. Res. (2018) 45:195-216 https://doi.org/10.1007/s13384-017-0250-y}

The article "What do students believe about effective classroom management? A mixed-methods investigation in Western Australian high schools", written by Helen Egeberg and Andrew McConney was originally published electronically on the publisher's internet portal (currently SpringerLink) on 1 December 2017 without open access.

With the author(s)' decision to opt for Open Choice the copyright of the article changed on 9 January 2019 to (CThe Author(s) 2019 and the article is forthwith distributed under the terms of the Creative Commons Attribution 4.0 International License (http://creativecommons.org/licenses/by/4.0/), which permits use, duplication, adaptation, distribution and reproduction in any medium or format, as long as you give appropriate credit to the original author(s) and the source, provide a link to the Creative Commons license and indicate if changes were made.

The original article has been corrected.

Open Access This article is distributed under the terms of the Creative Commons Attribution 4.0 International License (http://creativecommons.org/licenses/by/4.0/), which permits use, duplication, adaptation, distribution and reproduction in any medium or format, as long as you give appropriate credit to the original author(s) and the source, provide a link to the Creative Commons license and indicate if changes were made.

\footnotetext{
The original article can be found online at https://doi.org/10.1007/s13384-017-0250-y.

Helen Egeberg

h.egeberg@ecu.edu.au

1 Edith Cowan University, 2 Bradford Drive, Mt Lawley, WA 6050, Australia

2 Murdoch University, 90 South Street, Murdoch, WA 6150, Australia
} 